\title{
Perspective on Large Cardamom Cultivation and its Challenges in West Sikkim, India
}

Sushmita Chakraborty ${ }^{+*}$ and Namita Chakmaî

\section{Abstract}

Sikkim is the smallest mountainous state in North-East India. Agriculture is the backbone of rural Sikkim. It contributes $16 \%$ of the Gross Domestic Product (GDP) of the State and supports more than $64 \%$ of the population. In 2015, Sikkim Organic Mission was launched, and the focus was shifted from subsistence to commercial agriculture. Farmers shifted their choice from food crop cultivation to large cardamom cultivation for high-profit making purposes. Presently, cardamom cultivation in West Sikkim suffers from challenges like maintaining the quality of the product and lack of scientific technique to tackle the situation.

Keywords: Large Cardamom, Commercial Agriculture, Sikkim, North-East India, India

\footnotetext{
${ }^{+}$Research Scholar, Department of Geography, The University of Burdwan, Barddhaman, West Bengal, India ${ }^{*}$ Corresponding Author, Email: sushmita.chakraborty8@gmail.com

îAssistant Professor, Department of Geography, The University of Burdwan, Barddhaman, West Bengal, India, E-mail: namitachakma@gmail.com

(C) 2019 Chakraborty and Chakma. This is an Open Access article distributed under the terms of the Creative Commons Attribution License (http://creativecommons.org/licenses/by/2.0), which permits unrestricted use, distribution, and reproduction in any medium, provided the original work is properly cited.
} 


\section{Introduction}

International Centre for Integrated Mountain Development (ICIMOD), 2016, reported that "agricultural landscape of Sikkim has undergone a rapid transformation due to the impact of globalisation. Genetic resources and traditional knowledge system also deteriorates at a significant level". Since the 1975-76, farmers began to use chemical fertilisers in the field (Subba, 2014) but it failed to perform well (Sharma et al., 2000). Later, the Sikkim government adopted a mission in 2003 to transform the State into a "Total Organic State". Finally, Sikkim organic mission was launched on 15 th Aug, 2015 (Food Security and Agricultural Development Department, Government of Sikkim, 2013 and Subba, 2011) where spice crop large cardamom (Amomum subulatum Roxb, locally called Allainchi, a perennial herb) becomes the substantial part of livelihood option (Subba, 2008, 2014, Khura et al., 2013, Sharma et al., 2000) in rural areas of the whole Sikkim and West Sikkim is no exception of this.

Sikkim is the home of myriads of indigenous communities who have their very own knowledge system. There is a close-knit with a variety of landscape and spatial change of agriculture characters. Traditional agroforestry includes rice cultivation ('Khet' system, along with the river valleys of 300 metres) aldercardamom, a farm-based system (600-2200 metre) and Tibetan agro-pastoralism (4000-6000 metre) (Subba, 2011). In the study area, only the first three are practised. At the time of the British Protectorate (1817-1947), there was a mass clearing of forests mainly because of the establishment of the Nepali settlement (Sinha, 2008). Terraced and shifting cultivation was introduced after 1914. In 1980, the mixed system emerged with a combination of agroforestry and livestock farming. Farmers being a social actor, always have the tendency to maintain the community based productive practices, but with time, the agricultural system has changed. Cardamom is the age-old spice crop in Sikkim and capsules were grown in natural forest areas adapting with the natural environment (Sharma et al., 2000, Bhattarai et al., 2013), but when communities realised that, capsules are high-profit making, they shifted their choice to cardamom cultivation.

The main aim of the present work is to analyse the harvesting operation of large cardamom cultivation where adaptation of conventional and modern techniques in crop cultivation remains an important aspect of the study. Market centres are the first contact place of the farmers where the price of cardamom is prepared, and the whole marketing function is developed. Thus the market and export scenario of the product also become important parts of this study. Finally, the study tries to highlight the associated problems of large cardamom cultivation in the study area.

\section{Literature Review}

Cardamom is known as the 'king of spices', and it was used since Egyptian and Roman Empire period. The fascinating aroma, high nutrient content and self-propagation character made this a crucial commercial crop (Prabhakaran, 2011). Middle American country - Guatemala is the leading producer and exporter of larger cardamom in the world $(38,453 \mathrm{MT}$ in 20122013, value US\$217.5 million). Elettaria cardamomum is known as the 'Green Gold' of Guatemala, and the main exporting zone lies in the Middle East (Global Agricultural Information Network, USDA, Foreign Agricultural Service, 2014). In India, apart from Sikkim, Kerala is also famous for cardamom cultivation (small cardamom, Elettaria cardamommum) (Belcher, 2004) but the farmers of Kerala face challenges during export of this spice crop because the price of Guatemala cardamom is cheaper than Kerala cardamom (Times of India, 2014). In Asian country like Lao PDR, Vietnam, cardamom is also an important non-timber cash oriented forest product which secures the food security of the upland farmers, and local varieties of cardamom cultivation are continuously encouraged by the government of this country (Belcher, 2004). This crop is enriched with protein and carbohydrates, and it has social, economic and religious significance in various parts of the world, but 
mostly it is used in culinary purpose (Cumo, 2013). Valuable perennial cash crop large cardamom has immense medicinal and industrial significance, and $85 \%$ of large cardamom is being exported from Indian State, Sikkim. By enhancing the high yielding capacity of seeds and sustainable production procedure its future may be secured well (Chempakam and Zacharia, 2008).The next section presents the data source and methods.

\section{Data Sources and Methods}

In the present study, in-depth empirical research had been carried out. Primary data has been collected from farmers, cardamom dealers and government offices through a structured questionnaire survey in West Sikkim. Qualitative techniques include focus group discussions and interviews. Purposive sampling technique has been used in the sample selection procedure. Secondary data sources include Export shipment data of Indian customs, 2016 and annual report from Spice Board of India, 2014-2016.

\section{Discussion}

\section{Large Cardamom Cultivation: Pre and Post- Harvest Operation Processes}

Varieties of large cardamom locally called as, Ramsey, Seremna, Bharlangey, Golsey (large size seed) Sawney, Ramsai, and Ramla (small size seed). Seremna has the highest yielding capacity, suitable for dry areas, requires less irrigation, fewer shades and harvested in August (Subba, 2014). The quality of cardamom depends upon the size of the capsules. Gol dana ('Gol' means rounded, and 'dana' means capsules) Seremna is the best quality cardamom which cost about ₹ 70,000 for $40 \mathrm{Kgs}$. because an outward cover of the seed is thin and the number of seeds on the capsules is high (70-80 seeds per capsules). Bharlangey is very robust, having a pseudo stem of 2.5 metres long, large leaves, 15-20 capsules with 40-60 seeds in each capsule. In case of Golsey variety, it is less vigorous, greenish to maroons in colour, capsules are rounded, and there are 40-50 seeds per capsules. Moist and well drained sandy loam soil is most suitable for cardamom cultivation.

Field preparation is an important step following primary nursery bed preparation (Figure 1) at middle to a lower altitude $(600-1350 \mathrm{~m})$ for better germination (which will reduce at high altitude). It needs open space and a gentle slope to avoid water-logging. Farmers use well-rotted farmyard manure of about $5 \mathrm{~kg}$ for per square metre area of nursery bed.

Sand, silt and dry leaves are used to cover the seeds followed by water spray (necessary to keep the seedbed moist). After this, germination starts and continue up to 3 months then seeds are shifted to secondary nursery field where they kept it in a row to row $90-150 \mathrm{~cm}$ and plant to plant 2-meter distance. After 15-16 months of germination, healthy seedlings are ready to transplant in the main field. Young plantation needs proper management mainly in case of adequate shade regulation, weeding, pest management, removal of diseased and died plants, and controlling waterlogging. Organic manure includes leaf litters (pseudostems, spikes, leaves rich in organic matter), cow dung and cow urine (Sharma et al., 2009 and Food Security and Agricultural Development Department, Sikkim, 2013). After the pollination leaves, pseudostems, weed and stubbles are removed. When the top capsules of the spikes attain dark grey colour, harvesting starts. Firstly, the mature spikes are cut, then the pseudostems are removed (Subba, 2014).

Before the beginning of the drying process, each capsule needs to be separated from the bunch of flowers and needs to be cleaned. (Mande et al., 1999). The moisture level of the capsules must be at below $10 \%$ through drying (heat not more than $50 \circ \mathrm{C}$, as it may damage the natural colour and flavour) in a curing chamber (Bhattis). After curing, the capsules are ready for packing, marketing and export. 


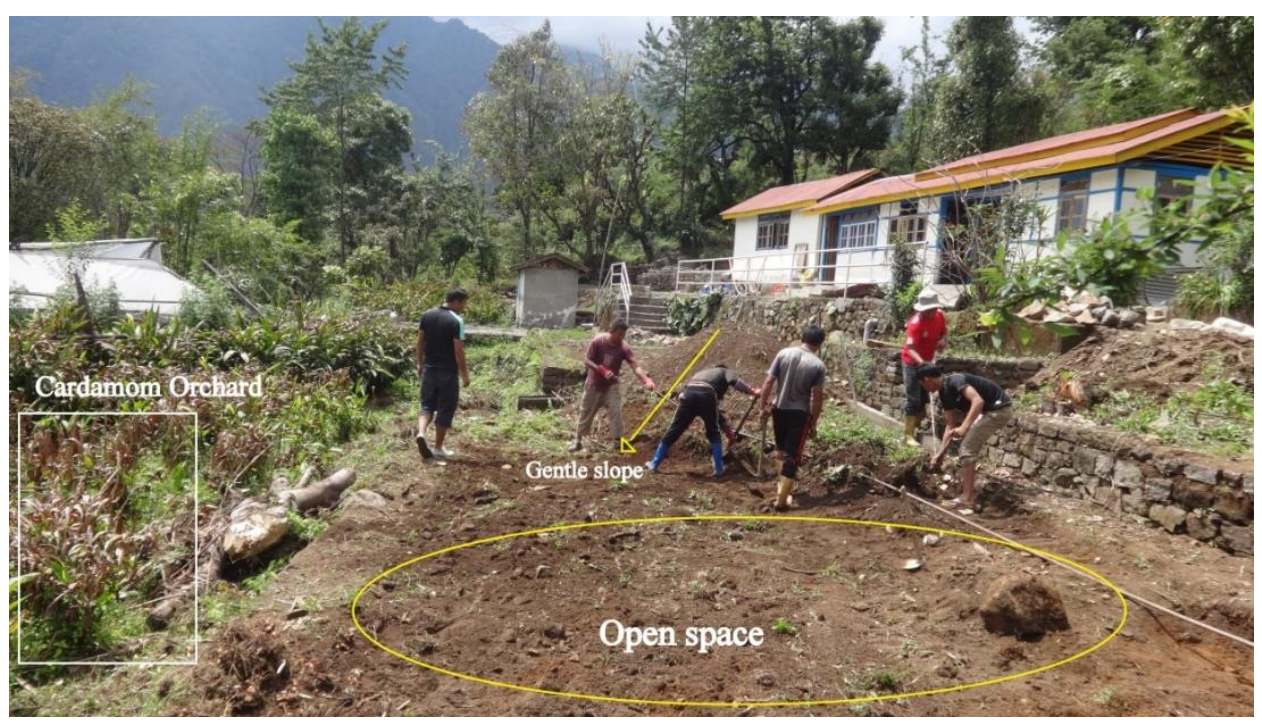

Figure 1: Primary Nursery Bed Preparation at Yuksam. Source: Field Survey

Capsules curing is an age-old practice in Sikkim where seeds are exposed on fire, but excessive fire and smoke causes poor quality and dry product (Kishore and Rastogi, 1987). It takes 3540 hours for drying of capsules, but due to higher exposer on fire, it causes $350-550 \mathrm{~kg}$ moisture evaporated leading to decrease in the aroma. It also leads to 4-9 kg fuelwood consumption for per kg drying of cardamom along with 15-25 $\mathrm{kg} /$ hour fuel burning rate (Mande et al., 1999). Presently, the traditional system of Bhatti (Figure 2) has been changed to modern technology in some limited areas where layout and construction materials have modified. Here, smoke emits through the flue-pipes which protects the colour and aroma of the seeds (Figure 3). Farmers still are more frequent to use the traditional Bhatti system.

Though Tata Energy Research Institute (TERI), has developed 'Gasifier system of curing chamber' which is fuel efficient, low cost and fast curing (Subba, 2014), still it has not been introduced in the selected study areas.

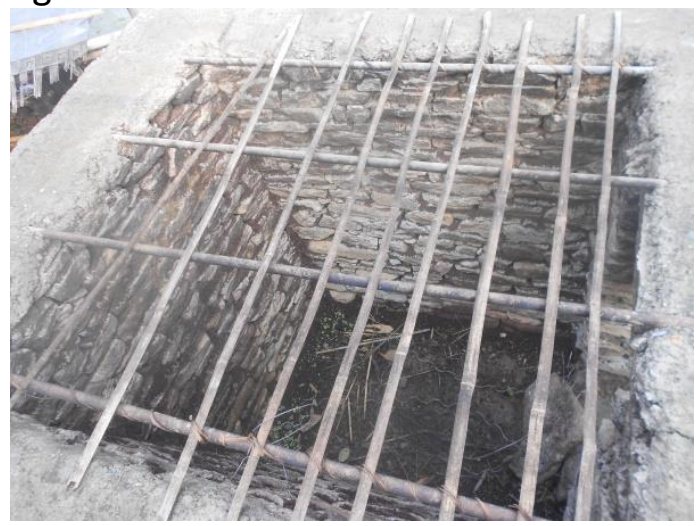

Figure 2: 'Bhatti' using firewood in Darap Source: Field Survey 


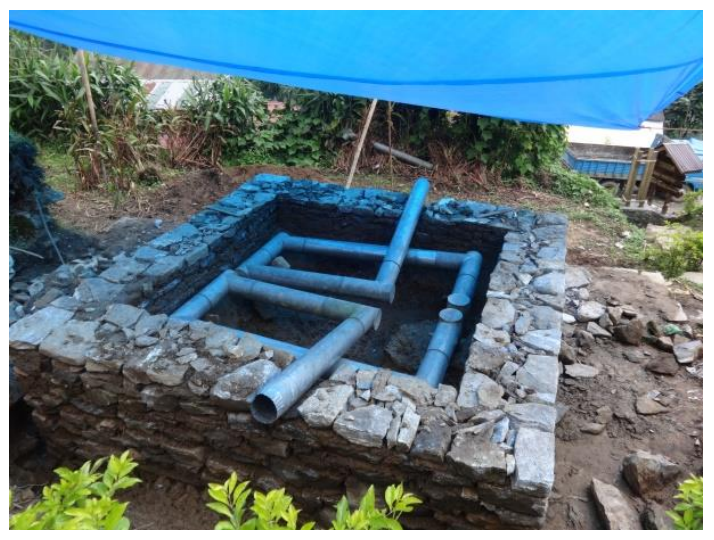

Figure 3: 'Bhatti' using flue-pipe; Source: Field Survey

\section{Marketing and Export of Large Cardamom}

Market centres in Sikkim follow a three-tier hierarchy system. Local centres are located in local GPUs, intermediate, and sub regional centres are located at Singtam and Rangpo (East Sikkim), and large regional market centre is located in Siliguri (West Bengal). These chain systems are managed by three separate groups of traders. Dealers or middle man exist in every mouzas. They transport the cardamom to Singtam and Rangpo, which are also major auction centres. After the auction, Marwari businessmen carry the product to Siliguri. It is saddening to note that political interference has also started with the introduction of the dealer system. Poor farmers have to go to the dealers selling the product. They offer them a certain price (well below the market price) and the farmers have to accept that. Apart from this chain, there are several collection centres JALAPA and MERMAC have been established in every village in the last two years, but these organisations have failed to continue their business due to the existence of unscrupulous means. To make the cardamom business fair enough, the Sikkim government have taken some initiatives. According to the specialists in Krishi Vigyan Kendra (KVK), Gyalshing, "Government have recently started Farmer Producing Organisation (FPO) in every GPUs. In West Sikkim, only two FPO have been set up till now in Budan and Rinchenpong area. It is a shareholder and co-operative system where the farmer can register and become a member. The main objective of the organisation is to make the farmer self-dependent. Thus, they can sell the product independently to the market".

According to the reports of state policy of organic farming in Sikkim by Food Security and Agricultural Development Department 2013, ICIMOD 2016 and 2017 and annual report from Spice Board of India by Ministry of Commerce and Industry in 2015 and 2016, cash income of Sikkim from cardamom has increased from $1.9 \mathrm{~m}$ USD in 1975 to $13.8 \mathrm{~m}$ in 2005. 'Sikkim contributes about $40 \%$ of the world production of large cardamom after Nepal' (Sharma et al., 2009). Export data (Figure 4), shows that the highest demand for spices is found in Pakistan and the Middle East especially the United Arab Emirates (UAE). From 2011-12 to 2012-13, the quantity exported to Pakistan had increased from 719.52 tonnes to 905.11 tonnes and maximum export achieved at 2013-14 with 967.86 tonnes. After 2013-14, export started to decline in Pakistan. During the survey, the dealers opined that due to the continued political unrest between the two countries, the cardamon business alongside other businesses has been profoundly affected. The period 201516 has been recorded as the lowest export (370.02 tonnes). As the cardamom had high demand in Pakistan and UAE, both price (₹7471.32 lakh in 2013-14) and the quantity of trading gained has been highest from Pakistan (Figures 4 and 5). In 2015-16, when export decreased, the price also declined (₹ 4999.26 lakh). The least price value is observed in the case of the USA in 2014-15 (₹105.51 lakh) (Figure $5)$. 
Though Sikkim government has strong legal corridor to resist the illegal export of cardamom seeds and saplings but the dealers opined that "there are some dealers who carry the cardamom saplings and seeds illegally to other countries (Nepal and Bhutan) and other States of North East India (Mizoram and Arunachal Pradesh) with the aim of earning huge profit, which ultimately becomes a threat to Sikkim's inherited cardamom varieties".

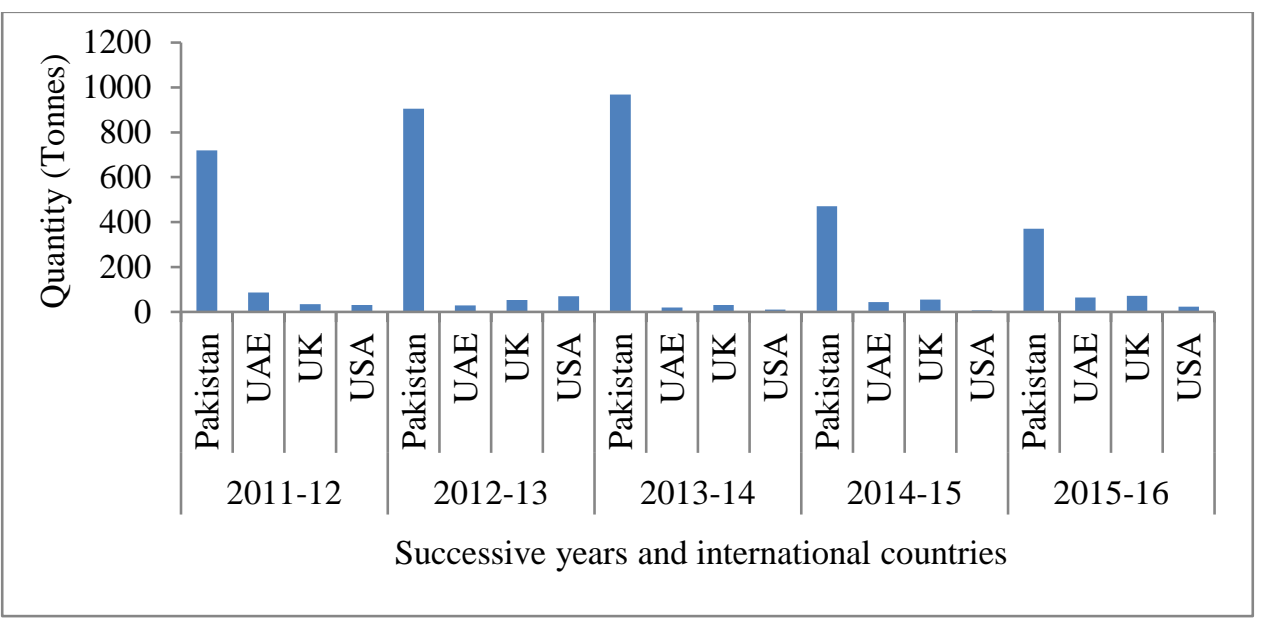

Figure 4: Quantity of Cardamom Exports in International Markets from 2011-2016 Source: Export Shipment Data of Indian Customs (ESDIC), 2016

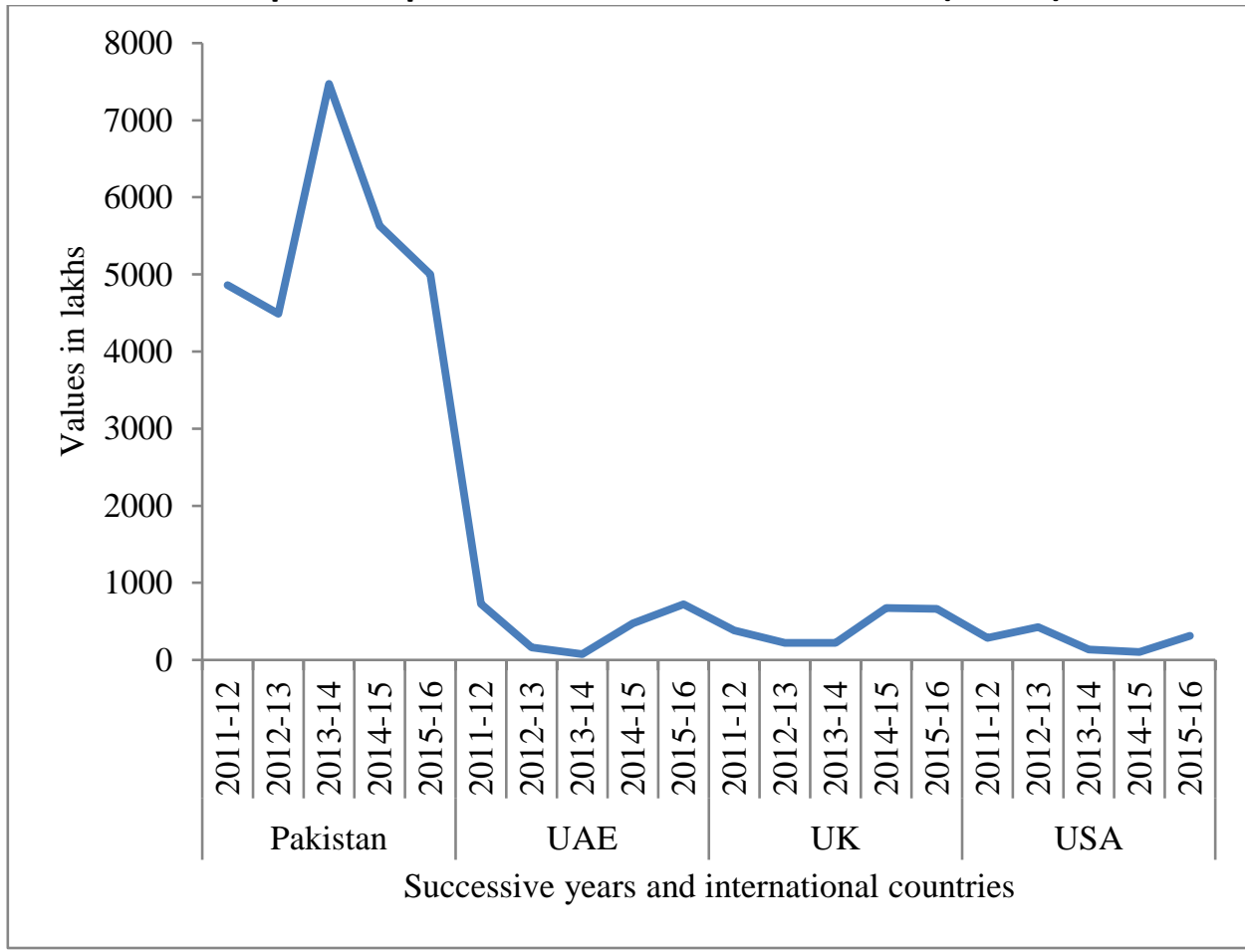

Figure 5 Values of Cardamom Export in International Markets from 2011-2016. Source: ESDIC, 2016

\section{Challenges of Large Cardamom Cultivation}

Cardamom continues its production up to 12 years, but after that, it started to lose its production. Farmers then were compelled to completely uproot the old plants and start preparing for a new plantation. Due to this rotational process, soil $\mathrm{pH}$ started to decline, and attack of pests and insects have become very frequent (Sharma et al., 2000). Farmers have also failed to maintain a $2 \mathrm{ft}$ gap between two cardamom plants (which causes the frequent spread of diseases from one plant to another) in addition to not planting shaded trees and other subsistence crops in the field thus, production of cardamom have faced rapid challenges. Soil 
scientists- B.K. Bhutia from KVK, Gyalshing opined that "we made lots of awareness programme to make the farmers aware about the future threat to cardamom and suggested them the best possible measures, but maximum farmers do not follow the programmes'. Some farmers told us that, "we do not plant shaded trees and other crops in cardamom field because, the portion of land which will be occupied by shaded trees and other crops, are replaced cardamom plant because we will get more profit'. Spice Board of India, 2014-15 and 2015-16, KVK, 2016 and 2017 have already suggested some possible measures to maintain future sustainability.

First, Gyalshing KVK with the collaboration of ICAR in Gangtok, Sikkim has prepared 'Biochar technology' to maintain soil $\mathrm{pH}$, reduce toxicity from soil and weed production from the field.

Second, shade-loving plants (Alnus nepalensis (Uttis), Schima Wallichii (Chillowne), Bucklandia Populnea (Pipali), Terminalia Myriocarpa (Panisaj), Castanopsis Spp (Kattus), Brassiopsis Mitis (Chuletro) should be planted in cardamom field to protect them from moisture evaporation and to maintain soil condition.

Third, Broom grass (non-timber forest product) should be used for management and conservation of soil in the denuded hilly tracts. The fibre root mats of broom grass effectively protect the topsoil and nutrient (Alam et al., 2017 and Sharma et al., 2000).

Fourth, Emphasis should be given to pollination and tissue culture. Cardamom is a cross-pollinated crop, consist of subterranean rhizomes (Khura et al., 2013, Deka et al., 2011) and it has the capability of self-pollination. Bumble honey bee act as a pollinator. The tissue culture will also help healthy seedling.

\section{Conclusion}

Cardamom cultivation has faced different challenges from diverse perspectives which have become a serious risk. Nepal has already followed some interesting features to restore the future productivity of cardamom. Water harvesting (ICIMOD, 2017) is one of them, to dig out ponds at a suitable location in the field will help the farmers to store rainwater during monsoon and from a nearby source which will help to restore soil moisture. Field-based ecological engineering for pest management and farmer's field school (ICIMOD, 2017) are other important methods for community participation. Genetic diversity of large cardamom can be increased through crossbreeding (Rao et al., 1993) and it can continue its production to a large extent (Subba, 2014). If the farmers can reach to the retailer directly, they would get the direct benefit. There are some extreme remote villages where farmers do not get training and awareness facilities, and they are not technologically abled. If KVK (Krishi Vigyan Kendra) and Panchayat members can make good connections with them, they will be benefitted. In the study area, most of the farmers belong from middle to old age (40-75) groups, and they are unable to get in touch with new technological initiatives. Hence, young generations' participation in cardamom sector is essential. According to KVK, kiwi cultivation (Actinidia Chinensis) and mushroom cultivation may also be taken as important livelihood options along with cardamom because it is also high-value crop and unused terraces and edges of the large cardamom farms can be converted to kiwi cultivation easily.

\section{References}

Alam, M. J., Islam, J. S. M., \& Rahman, M. M. (2017). Cultivation, Production and Management Techniques of Broom Grass (Thysanolaena Maxima Roxb.) in Hilly Areas of Bangladesh. Agriculture and Natural Resources. Science Direct, Elsevier. Retrieved from

http://www.journal.elsevier.com/agricultur e-and-natural-resources

Belcher, B. (2004). Forest Products, Livelihoods and Conservation- Case Studies of NonTimber Forest Product System. In K. Kusters (Eds.), Retrieved October 18, 2018, 
http://www.cifor.org/publications/pdf_files /Books/NTFPAfrica/TOC-Chapter6.PDF.

Bhattarai, N. K., Deka, T. N., Chhetri, P., Harsha, K. N., \& Gupta, U. (2013). Livelihood Improvement through Sustainable Large Cardamom Cultivation in North Sikkim. International Journal of Scientific and Research Publication, 3(5), 1-4. Retrieved from http://www.ijsrp.org

Chempakam, B., \& Zacharia, T. J. (2008). Chemistry of Spices. In V. A. Parthasarathy (Eds.). Retrieved October 19, 2018, from https://catbull.com/alamut/Bibliothek/Che mistry_of_Spices.pdf

Cumo, C. (2013). Encyclopedia of Cultivated Plants- From Accasia to Zinnia (Vol. 1). Retrieved October 18, 2018 https://www.abc-clio.com/ABCCLIOCorporate/product.aspx?pc=A3394C

Deka, N. T., Sudarshan, R. M, \& Saju, A. K. (2011). New Record of Bumble Bee, Bombus breviceps Smith as a pollinator of Large Cardamom. Current Science, 100, 926-928. doi:10.5958/2229-4473.2016.00080.X

Export Shipment data of Indian Custom. (2016). [Excell File]. Government of India. Retrieved from www.zauba.com

Food Security and Agricultural Development Department. (2013). Sikkim State Policy on Organic Farming. Retrieved from http://www.rvskv.net/TaskForce/Organic_fa rming_policy_sikkim.pdf

International Centre for Integrated Mountain Development. (2016). Agrodiversity in Sikkim Himalaya: Socio-Cultural Significance, Status, Practices and Challenges. Retrieved from http://www.icimod.org

International Center for Integrated Mountain Development. (2017). Climate-Resilient Practices for Sustainability of Large Cardamom Production System in Nepal. Retrieved from http://www.icimod.org

Karun, S. (2014, April 21). Kerala Cardamom trying to fight off its Guatemalan Cousin. Times of India. Retrieved from http://www.timesofindia.indiatimes.com
Kishore, N. V. V., \& Rastogi, S. K. (1987). Thermal Analysis of Cardamom Curing Chambers. Energy in Agriculture, 245-253. Retrieved from http://www.sciencedirect.com

Khura, T. N., Debbarma, J., Chandra, R.., Yadav, S., Chauhan, N. S., \& Rautaray, S. K. (2013). Physical Properties of Large Cardamom Cultivated in North Eastern Himalayan Region, Sikkim. Agriculture Engineering International, 15(4). Retrieved from http://www.cigrjournal.org

Mande, S., Kumar, A., \& Kishore, V. V. N. (1999). A Study of Large Cardamom Curing Chambers in Sikkim. Biomass and Bioenergy, 463-473.

Ministry of Commerce and Industry (2015). Annual Report from Spice Board 2014-2015. Government of India. Retrieved from www.indiaspices.com

Ministry of Commerce and Industry (2016). Annual Report from Spice Board 2015-2016. Government of India. Retrieved from www.indiaspices.com

Prabhakaran, K. P. N. (2011). Agronomy and Economy of Black Pepper and Cardamom-The 'King' and 'Queen' of Spices. Retrieved from https://www.elsevier.com/books/agronomy -and-economy-of-black-pepper-andcardamom/nair

Rao, Y. S., Anand, K., Chatterjee, S., Naidu, R., \& George, K. C. (1993). Large Cardamom (AmomumsubulatumRoxb)-A Review. Spice and Aromatic Crops, 21(2), 1-15. Retrieved from

http://updatepublishing.com/journals/index .php/josac

Sharma, E., Sharma, R., Singh, K., \& Sharma, G. (2000). A Boon for Mountain Populations: Large Cardamom Farming in Sikkim Himalaya. Mountain Research and Development, 20(2). Retrieved September 10, 2016, from http://www.researchgate.net

Sharma, G., Sharma, R., \& Sharma, E. (2009). Traditional Knowledge Systems in Large Cardamom Farming: Bio Physical and Management Diversity in Indian 
Mountainous Region. Indian Journal of Traditional Knowledge, 8(1), 17-22.

Sinha, A. C. (2008). Sikkim: Feudal and Democratic. New Delhi: Indus Publishing Company.

Subba, J. R. (2008). Indigenous knowledge on bio-resources management for livelihood of the people of Sikkim. Indian Journal of Traditional Knowledge, 8(1), 56-64. Retrieved from http://nopr.niscair.res.in/handle/123456789 /2965

Subba, J. R. (2011). History, Culture and Customs of Sikkim. New Delhi: Gyan Publishing House.
Subba. J. R. (2014). Organic Sikkim: Technology for Change. Gangtok: SYMS.

USDA Foreign Agricultural Service. (2014).

Guatemala, Global Agricultural Information Network. Retrieved from

https://gain.fas.usda.gov

\section{Acknowledgements}

We express our sincere gratitude to the Indian Council of Social Science Research (ICSSR), Government of India for their financial assistance. We are also thankful to the people of West Sikkim for supporting us during the field work. 